研 究 論 文

\title{
パルス管冷凍機のオリフィス部に生じる定常流と音響質量流
}

\author{
西谷 富雄, 柳井 正誼*, 田中 峰雄**, 児玉 隆夫** \\ 岩谷産業侏滋賀技術センター- 守山市勝部町 1095 \\ * 岩谷瓦斯(侏技術本部 尼崎市大高洲町 10 \\ ** 大阪市立大学理学部 大阪市住吉区杉本 3-3-138 \\ (1997 年 12 月 22 日受理)
}

\section{Investigation of Acoustic Streaming and Steady Flow at the Orifice of a Pulse Tube Refrigerator}

\author{
Tomio Nishitani, Masayoshi Yanal, ${ }^{*}$ Mineo Tanaka** and Takao Kodama** \\ Shiga Technology Center, Iwatani International Corporation, 1095 Katsube, Moriyama 524-0041 \\ * Technical Development, Iwatani Industrial Gases Corp., 10 Otakasu-cho, Amagasaki 660-0842 \\ ** Faculty of Science, Osaka City University, 3-3-138 Sugimoto, Sumiyoshi-ku, Osaka 558-0022
}

(Received December 22, 1997)

\section{Synopsis:}

In an orifice pulse tube refrigerator, the dynamic pressure-flow characteristics of the orifice were determined from experimental investigation for the purpose of calculating the accurate PV diagram in the pulse tube. The mass flow calculated from measured pressures on both sides of the orifice involves steady flow that is generated from steady pressure difference produced by acoustic streaming at the orifice. This steady flow compensates for the acoustic streaming and must be subtracted to calculate the PV diagram.

Keywords: pulse tube refrigerator, orifice, pressure-flow characteristics, acoustic streaming, steady flow

\section{1。はじめに}

スターリング冷凍機やギホード・マクマホン冷凍 機。ソルベイ冷凍機などの小型冷凍機では, 横軸にピ ストン（またはディスプレーサ）の変位, 縦軸に圧力 を取った PV 線図で性能を評価する方法が使われてい る。パルス管冷凍機の解析でも, ガス変位を断面で平 均した值を仮想的なガスピストン端面の変位と見な し、PV 線図を考えることができる11。各瞬間のガス 流量は熱線式流量計年やレーザー流速計尚, スモーク ワイヤー法4)などを使って測定されるが, 特別な装置 が必要であり, 誰でも手軽に使えるわけではない。

オリフィス両端の圧力を測定して, オリフィスの圧 力流量特性式から質量流量を計算し，パルス管の PV 線図を計算する方法 ${ }^{5,6}$ は, 冷凍機に特別な加工の必

Vol. 33 No. 4 (1998)
要がなく，簡単に見える。しかしこれまでの報告で は, 定常流体実験で得られた圧力流量特性式と流量係 数を使って解析をしていたため, 辻褛の合わない現象 はすべて圧力流量特性式と流量係数の誤差として処理 されてきた。別の方法として，オリフィス型やアクテ イブバッファ型パルス管冷凍機では, バッファの圧力 変化からパルス管に出入りするガス流量を計算する方 法もある7)。しかし圧力が変化する時にバッファ壁に 近いガスは等温的に, バッファ中心部のガスは断熱的 に振る舞う。各々の割合は運転条件や形状に依存し, 解析の精度を下げる。PV 曲線は計算できても, 冷凍 性能との定量的な比較をするだけの精度がなかった。

著者は計算精度を上げるため, オリフィスの動的な 圧力流量特性と流量係数を測定し，この圧力流量特性 式と流量係数を使ってオリフィスを通過するガス量を 


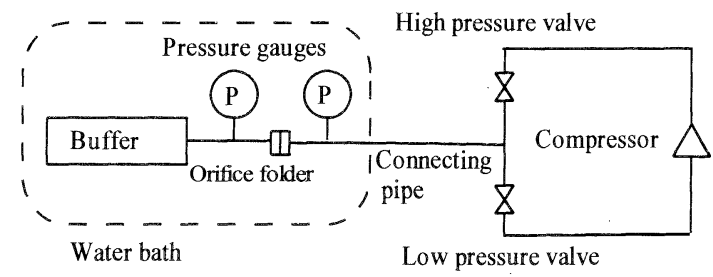

Fig. 1 Schematic of experimental device.

計算することを試みた。この過程でオリフィス部に， パルス管高温端からバッファに向かう音響質量流と, 逆向きの定常流が存在することを観察した。オリフィ ス雨側の圧力差にはこの定常流を誘起する圧力が加わ っており，PV 解析ではこの定常流成分を差し引く必 要がある。さらに音響質量流の大きさを熱音響理論か ら評価し，実験と良く一致することを確かめたので報 告する。1 段拈よび 2 段式パルス管冷凍機の PV 線図 と冷凍性能との関係は別の機会に報告する。

\section{2. 実験装置}

実験に使った装置の概略を Fig. 1 に示す。装置は, 圧縮機の低圧側に繫いだ低圧弁と，高圧側に繫いだ高 圧弁を，連結管を経由してオリフィスフォルダーとバ ッファに直接接続した構造である。バッファは銅管製 (内径 $26 \mathrm{~mm}$, 肉厚 $1 \mathrm{~mm}$, 長さ $200 \mathrm{~mm}$ ) で, ガス が等温変化をするように 40 メッシュの銅金網を充填 した。バッファの内容積は, 測定時の圧力変化割合が 冷凍機を $2 \sim 5 \mathrm{~Hz}$ で運転した時と同じ程度になるよ うに選んだ。さらに等温性を確保するため連結管から バッファまでの部品は水槽に付けた。オリフィス板 （直径 $10 \mathrm{~mm}$ ，肉厚 $1 \sim 5 \mathrm{~mm}$ ） は穴形状と穴寸法を 投影機で検查後，オリフィスフォルダーに組み込ん だ。オリフィス両端の圧力は圧力変換器（長野計器, KH 17）で測定した。

\section{3. オリフィスの圧力流量特性式}

\section{1 板状オリフィス}

圧力流量特性式と流量係数を決めるために次の手順 で測定を行った。初めにバッファを低圧に保つ。高圧 弁を開き，圧力変化を測定する (Fig. 2)。バッファ内 が高圧に達したら高圧弁を閉じる。バッファ内のガス の質量変化 $\mathrm{d} m$ と圧力変化 $\mathrm{d} p$ は $\mathrm{d} m=V M / R T_{\mathrm{b}} \cdot \mathrm{d} p$ の関係がある。 $V$ はバッファ容積， $M$ はへリウムの 原子量，R はガス常数， $T_{\mathrm{b}}$ はバッファ温度である。

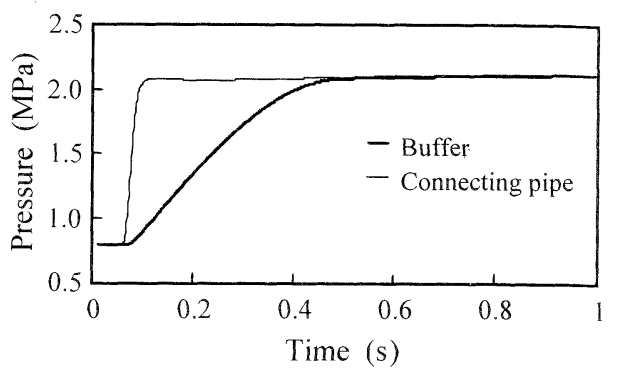

Fig. 2 Typical pressure changes at both sides of the $0.7 \mathrm{~mm}$ orifice when high-pressure gas is supplied to low-pressure buffer. Thick line represents the buffer pressure and fine line represents the connecting pipe pressure.

オリフィスの压力流量特性式( は己れまでの報告で 種々の式が使われているが，著者は以下に示すように (1)式が良く合うことを確認した。wはオリフィスを 通過するガスの質量流量， $C_{\mathrm{d}}$ はオリフィスの流量係 数， $A$ はオリフィスの開口面積， $\kappa=5 / 3$ はガスの比 熱比， $\rho$ は密度， $P$ は圧力で, 添字 1 は上流側, 添字 2 は下流側を表す。

$$
w=c_{\mathrm{d}} A \sqrt{\frac{2 \kappa}{\kappa-1} P_{1} \rho_{1}\left\{\left(\frac{P_{2}}{P_{1}}\right)^{\frac{2}{\kappa}}-\left(\frac{P_{2}}{P_{1}}\right)^{\frac{(\kappa+1)}{\kappa}}\right\}}
$$

状態方程式 $\rho_{1}=P_{1} M / R T_{1}$ を使って書き換える。

$$
w=c_{\mathrm{d}} A P_{1} \sqrt{\frac{5 M}{R T_{1}}} \sqrt{\left(\frac{P_{2}}{P_{1}}\right)^{1.2}-\left(\frac{P_{2}}{P_{1}}\right)^{1.6}}
$$

$\mathrm{d} m=w$ なので, 流量係数 $c_{\mathrm{d}}$ は $c_{\mathrm{d}}=\mathrm{d} m /\left(w / c_{\mathrm{d}}\right)$ か ら決まる。

流量係数 $c_{\mathrm{d}}$ とオリフィス両端の圧力差 $\Delta P=P_{1}$ $P_{2}$ の関係の測定例を Fig. 3 に示したが，流量係数 は圧力差に依らず一定である。詳しく見ると圧力差が 小さい領域で流量係数が一定值からずれている。しか し実際にパルス管冷凍機を運転した圧力デー夕を見る

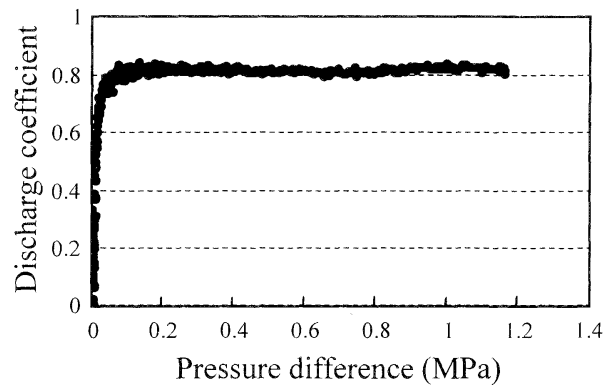

Fig. 3 The discharge coefficient $\left(c_{\mathrm{d}}\right)$ of the $0.7 \mathrm{~mm}$ orifice calculated from the charging process.

低温工学 
と圧力差が小さい時間はほとんどないので，このずれ は計算に影響しない。結局，(1)式を動的な圧力流量 特性式として使用できる。測定したオリフィス穴径 $0.4 \sim 0.8 \mathrm{~mm}$, 板厚 $1 \sim 5 \mathrm{~mm}$ の範囲で, 流量係数は

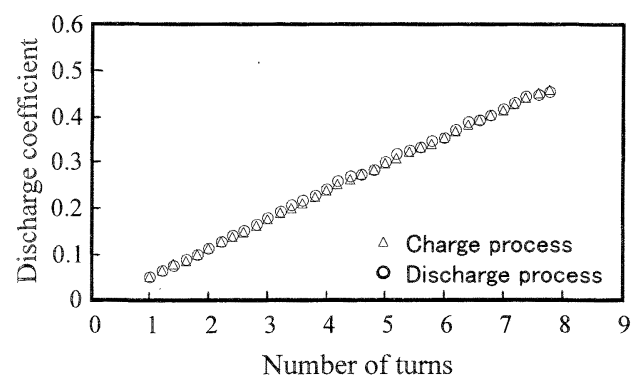

Fig. 4 The discharge coefficients $\left(c_{\mathrm{d}} A\right)$ of needle valve in the normal direction coincide with each other during charging and discharging processes.

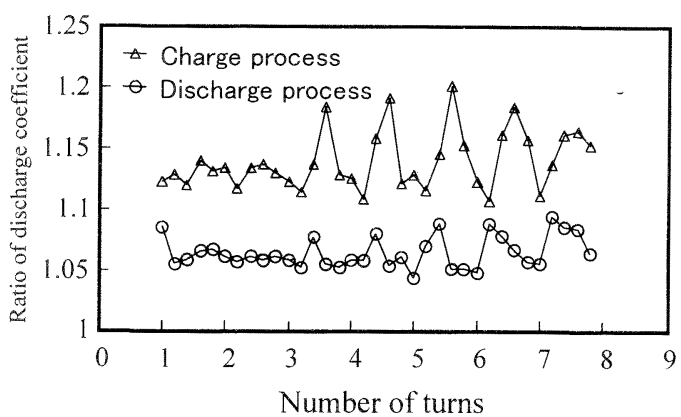

Fig. 5 The discharge coefficients $\left(c_{\mathrm{d}} A\right)$ of needle valve in the opposite direction differ from each other during charging and discharging processes. The ratio of discharge coefficients of opposite versus normal direction flow of the needle valve are oscillated with the number of rotations.

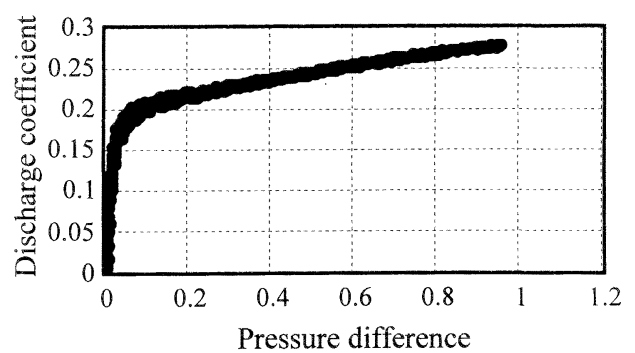

Fig. 6 The discharge coefficient $\left(c_{\mathrm{d}}\right)$ of the capillary tube is not constant. Equation(2) cannot be used for the capillary tube.
板厚 $L(\mathrm{~mm})$ だけの関数で $c_{\mathrm{d}}=0.81-0.0075 L$ となっ た。

\section{2 他の形状のオリフィス}

パルス管冷凍機の実験でよく使われているニードル 弁（Nupro，B-4 MG 2 型）とキャピラリーチューブ （内径 $1.61 \mathrm{~mm}$ ，長さ $1 \mathrm{~m}$ ）も同様に測定した。

ニードル弁は向きによって流量係数が異なるため, バルブに指定された向きを順方向，反対向きを逆方法 と呼ぶ。また開口面積 $A$ が決められないため， $c_{\mathrm{d}}$ の 代わりに $C_{\mathrm{d}} A$ を流量係数とし，ニードル弁の回転数 との関係を調べた（Fig. 4)。ガスを順方向に流した 場合は，バッファを充填しながら測定した時と放出し ながら測定した時とで流量係数 $C_{\mathrm{d}} A$ に差はなかった。 ガスを逆方向に流した時は差があった。逆方向の流量 係数 $C_{\mathrm{d}} A$ を順方向の流量係数 $C_{\mathrm{d}} A$ で割ると, 回転数 による振動現象が見られた（Fig. 5)。振動の原因は ニードル弁の軸のズレなどが考えられるが確かめてい ない。ともかくニードル弁を使った場合には，運転中 の圧力条件によって流量係数を変える必要がある。

キャピラリーチューブは(2)式に合わず（Fig. 6)， 別の圧力流量特性式を見つける必要がある。

\section{4．音響質量流と定常流}

\section{1 振動流での測定}

圧力流量特性式(2)を実際の振動流に適用するため, 圧力が一定周期で変化する条件で測定した。実験に使 ったシステムはFig. 1 と同じである。Fig.7(a) はオ リフィス径 $0.7 \mathrm{~mm}$, 板厚 $1 \mathrm{~mm}$, 周波数 $2.4 \mathrm{~Hz}$ の

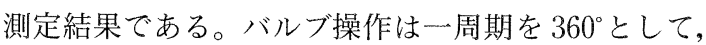
0。で高圧弁を開き，95で高圧弁を閉じ，180で低圧弁 を開き， $275^{\circ}$ で低圧弁を閉じた。

Fig. 7(a)を見ると両方のバルブが閉じている時間 帯 $\left(95^{\circ} \sim 180^{\circ}\right.$ と $\left.275^{\circ} \sim 360^{\circ}\right)$ の後半に圧力差が一定の 時間がある。Fig. 7(b)，(c)にこれを拡大した。压力 差はどちらも同じ值 $\Delta P_{\mathrm{M}}=0.036 \mathrm{MPa}$ である。Fig. 8(a) は 95〜 $180^{\circ}$ の時間帯の途中でバルブを停止した 時の圧力変化で, 0.5 秒以内に圧力差が消失してい る。Fig. 8(b) は再運転した時の圧力変化で, 一周期 後に圧力差が回復している。この結果は圧力差が圧力 振動のある時にのみ存在し, 全てのバルブが閉まって いてガス流がない状態でも存在することを表してい る。これは音響理論から予想されている音響質量流の 特徴に一致する。 


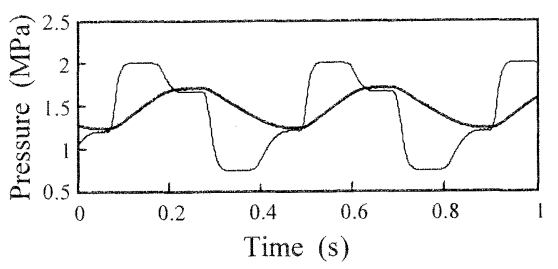

(a)

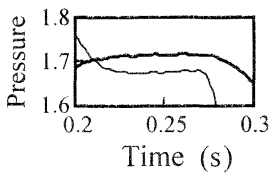

(b)

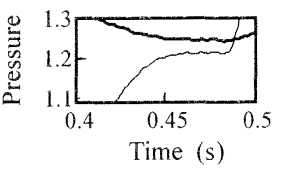

(c)
Fig. 7 (a) Pressure change on cyclic operation. Thick line represents the buffer pressure and fine line represents the connecting pipe pressure. (b) Magnified figure of steady pressure difference after the high-pressure valve is closed. (c) Magnified figure of steady pressure difference after the low-pressure valve is closed.

\section{2 音響質量流}

音響質量流は密度変化を伴う振動流中に生じる定常 的な流れで, 流体方程式の非線形性に起因する。音波 の領域では音響質量流は代表的な非線形音響現象の 1 つとして知られており, 特に超音波領域で数多くの実 験報告がある9)。熱音響理論によると振動流体中の質 量流 $\dot{m}_{\text {total }}$ は(3) 式で表される ${ }^{10,11)}$ 。(3) 式中の $J_{\mathrm{AS}}$ が音 響質量流である。それ以外の定常流を $J_{\mathrm{M}}$ で表す。 は速度振幅を表し, 流速 $U$ は平均流速 $u_{\mathrm{m}}$ を用いて $U=u_{\mathrm{m}}+u$ と表される。同様に $p$ は压力振幅で, 压 力 $P$ は平均圧力 $p_{\mathrm{m}}$ を用いて $P=p_{\mathrm{m}}+p$ と表される。

$K_{\mathrm{S}}$ は断熱圧縮率， $\beta$ は熱膨張率， $C_{\mathrm{p}}$ は定圧比熱， $S$ はエントロピー, $<>_{\mathrm{t}}$ は時間平均, $<>_{\mathrm{r}}$ は断面積 での平均である。

$$
\begin{aligned}
& \dot{m}_{\mathrm{tota} 1}=\dot{m}_{\mathrm{osc}}+J_{\mathrm{M}}+J_{\mathrm{AS}} \\
& \begin{aligned}
J_{\mathrm{AS}} & \equiv\left\langle\langle\rho \cdot u\rangle_{\mathrm{t}}\right\rangle_{\mathrm{r}} \\
& =\rho_{\mathrm{m}} K_{\mathrm{S}}\left\langle\langle p \cdot u\rangle_{\mathrm{t}}\right\rangle_{\mathrm{r}}+\frac{\beta}{C_{\mathrm{p}}} \rho_{\mathrm{m}} T_{\mathrm{m}}\left\langle\langle S \cdot u\rangle_{\mathrm{t}}\right\rangle_{\mathrm{r}}
\end{aligned}
\end{aligned}
$$

オリフィス型パルス管冷凍機では質量流 $\dot{m}_{\text {total }}$ と振動 流 $\dot{m}_{\mathrm{osc}}$ の時間平均はともにゼロなので, 音響質量流 $J_{\mathrm{AS}}$ を相殺する定常流 $J_{\mathrm{M}}$ がなければならない。

オリフィス部での粘性境界層の厚さ $\delta_{\nu} \equiv \sqrt{2 \nu / \omega} と$ 粘性緩和時間 $\tau_{\nu} \equiv r_{0}{ }^{2} / 2 \nu$ は $\left(\nu=12.48 \times 10^{-6} \mathrm{~m}^{2} / \mathrm{s}\right.$ と $\omega=2.4 \mathrm{~Hz}$ を使って), $\delta_{\nu}=3.22 \times 10^{-3} \mathrm{~m}$ と $\tau_{\nu}=$

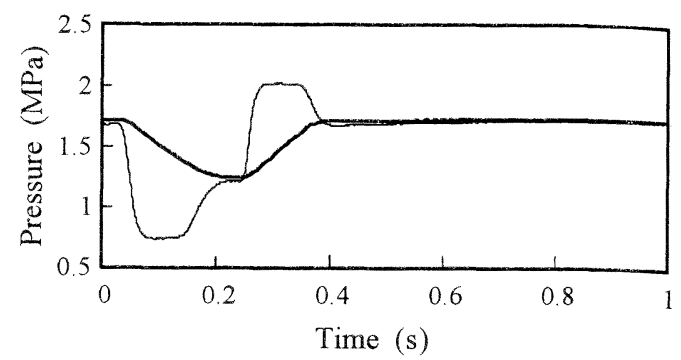

(a)

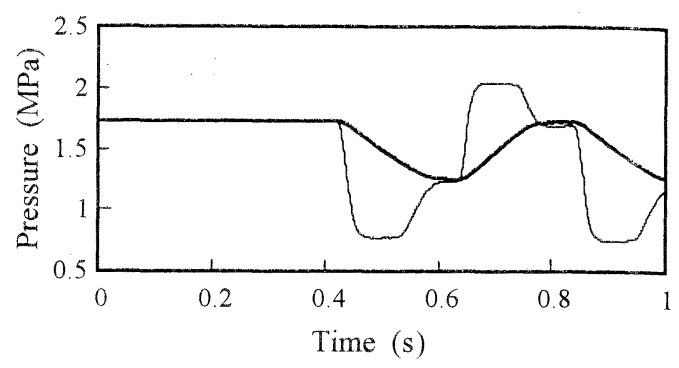

(b)

Fig. 8 (a) The steady pressure difference vanished within $0.5 \mathrm{~s}$ after the valve stopped suddenly. (b) The steady pressure difference is recovered in one cycle after restarting valve.

$3.6 \times 10^{-3} \mathrm{~s}$ である。 $\omega$ が $\tau_{\nu}$ に比べ極端に大きく，才 リフィス径が $\delta_{\nu}$ に比べ小さいので速度振幅の位相は オリフィス断面で一様である。そこで〈〈p・u $\left.\rangle_{\mathrm{t}}\right\rangle_{\mathrm{r}} \approx$ $\left\langle p \cdot\langle u\rangle_{\mathrm{r}}\right\rangle_{\mathrm{t}}$ が成り立つ。さらに $K_{\mathrm{S}}=1 / p_{\mathrm{m}} \gamma, \rho_{\mathrm{m}}=$ $M p_{\mathrm{m}} / R T, S=c_{\nu} \ln T$ の関係を使うと(4) 式になる。 この式の第 2 項は等温過程ではゼロになる。

$$
J_{\mathrm{AS}}=\frac{M}{\gamma R T_{\mathrm{m}}}\left\langle p \cdot\langle u\rangle_{\mathrm{r}}\right\rangle_{\mathrm{t}}-\frac{M p_{\mathrm{m}}}{R T}\left\langle\ln \frac{T}{T_{\mathrm{m}}} \cdot\langle u\rangle_{\mathrm{r}}\right\rangle_{\mathrm{t}}
$$

$\mathrm{Lee}^{4) や}$ 矢崎 ${ }^{12)}$ はパルス管中で音響質量流を観察し た。しかしオリフィス部で，このような音響質量流と 定常流の存在はこれまで報告されていない。

\section{3 定常流の補正}

音響質量流と定常流が存在すれば Fig. 7 で測定し たオリフィス雨端の圧力差 $\Delta P_{\text {tota1 }}$ には定常流 $J_{\mathrm{M}}$ を誘 起する圧力差 $\Delta P_{\mathrm{M}}$ が含まれているはずである。Fig. 9 は測定圧力差 $\Delta P_{\text {total }}$ から流量 $\int\left(\dot{m}_{\mathrm{osc}}+J_{\mathrm{M}}\right) \mathrm{d} t$ を計算 した結果で, 確かに定常流 $J_{\mathrm{M}}$ による見掛けのドリフ トが生じている。Fig. 7(a)，（b）で観測された压力差 $\Delta P_{\mathrm{M}}$ を引いた $\Delta P_{\mathrm{osc}}=\Delta P_{\mathrm{tota1}}-\Delta P_{\mathrm{M}}$ から $\int \dot{m}_{\mathrm{osc}} \mathrm{d} t$ を 計算するとこのドリフトが消える（Fig. 10）。 


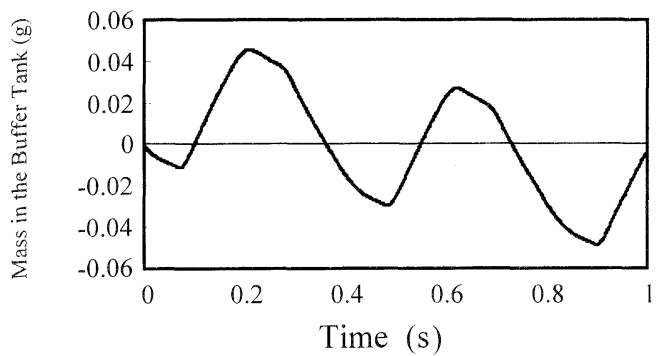

Fig. 9 The false mass drift caused by the steady flow is calculated from the pressures on both sides of the orifice.

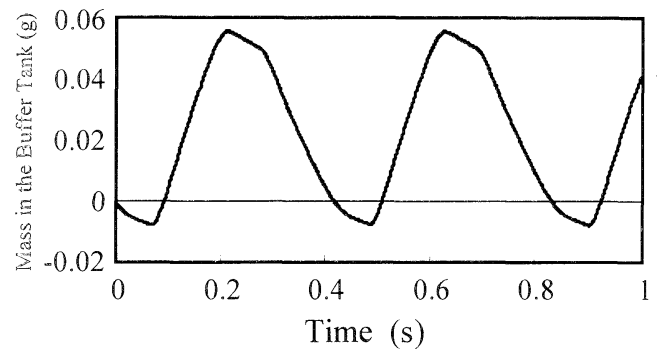

Fig. 10 The real mass flow calculated from the oscilating pressure after substracting steady pressure.

残念ながら実際のパルス管冷凍機では圧力差 $\Delta P_{\mathrm{M}}$ を観測できない場合が多い。そこで全流量 $\int\left(\dot{m}_{\mathrm{osc}}+\right.$ $\left.J_{\mathrm{M}}\right) \mathrm{d} t$ を計算した後, ドリフト分を定常流 $J_{\mathrm{M}}$ として 引き算する。定常流が音響質量流から誘起することを 確かめるため, 質量流のドリフトから計算した定常流 と，(4)式の第 1 項から計算した音響質量流との大き さをFig. 11 に比較した。両者は良く一致しており, 観測された圧力差は音響質量流によって形成された圧 力差と考えられる。

ダブルインレット型等の第三世代パルス管冷凍機で ほ定常流と音響質量流が相殺するとは限らず，差が DC 流として残る可能性がある。(4)式の第 1 項を計 算する方法では，DC 流の有無と向きを評価する精度 がなく，もっと精度の高い計算方法が必要である。

\section{马. オリフィス型パルス管冷凍機中の音響質量流}

実際のパルス管冷凍機でもオリフィス部で定常流と 音響質量流が発生していることを確認するため，一段 ホリフィス型パルス管冷凍機で測定した。オリフィス 灾穴径 $0.5 \mathrm{~mm}$ ，板厚 $1 \mathrm{~mm}$ を使い，温度を変えるた ぬに0〜15W の負荷を加えた。測定した圧力から質

Vol. 33 No. 4 (1998)

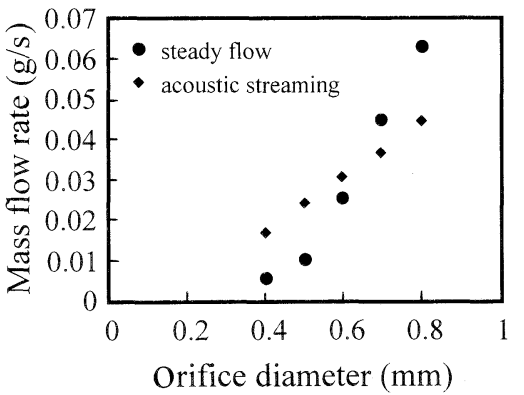

Fig. 11 The steady flow calculated from the mass drift agrees approximately with the acoustic streaming calculated from Eq. (4).

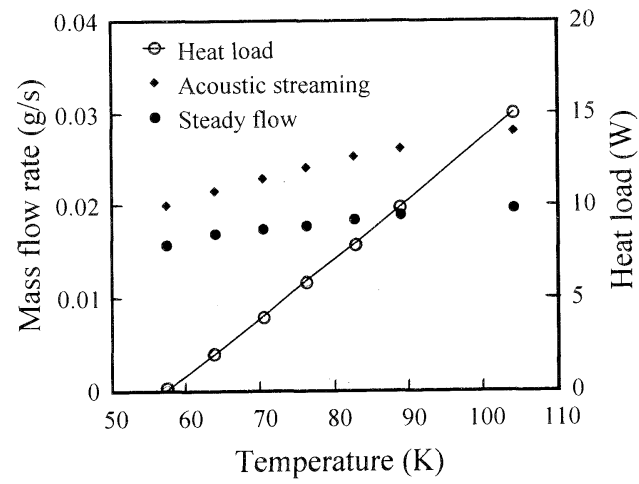

Fig. 12 In a single-stage orifice pulse tube refrigerator, the steady flow agrees approximately with the acoustic streaming $\$$. Heat load (thick line) of 0 to $15 \mathrm{~W}$ was added to change the temperature.

量流を計算した後, ドリフト分を定常流 $J_{\mathrm{M}}$ とした。 Fig. 12 に定常流 $J_{\mathrm{M}}$ と (4) 式から計算した音響質量流 $J_{\mathrm{AS}}$ の大きさを比較した。実際のパルス管冷凍機でも 確かに音響質量流が存在し, 定常流による見掛けのド リフトを生じていることが確かめられた。

\section{6. 結 論}

従来の解析では定常流や音響質量流の存在は考慮さ れておらず，質量流が一周期後に元の值に戻ることを 前提にしていた。当然, 定常流や音響質量流は見えな かった。しかし改めて(4)式を見ると,オリフィス部 では圧力振幅が $0.6 \mathrm{MPa}$ 程度, 速度振幅の最大值が 音速の 1 割程度と大きく, さらに圧力振幅と速度振幅 が同位相に近いため，音響質量流が圧力測定で観測に 
掛かる大きな值となっても不思議はない。これまで, 理論的には予想されていても通常の測定では無視でき ると思われていた音響質量流が，圧力を測定するだけ で観測可能なことを確認できたと考えている。

以上をまとめる。

1）パルス管冷凍機のオリフィスに適用できる圧力 流量特性式を動的測定で選定し, 流量係数を決 定した。

2）オリフィス部に音響質量流と定常流が存在する ことを観測した。

3）圧力測定から質量流量を計算するときには定常 流を引き算する必要がある。

4）この方法で観測された音響質量流の大きさは熱 音響理論からの計算値とほぼ一致する。

\section{参考文 献}

1) Y. Matsubara, et al.: An experimental and analytical investigation of $4 \mathrm{~K}$ pulse tube refrigerator, Cryocoolers 7 Part 1 (1993) 166

2) M. David, et al.: Measurements of instaneous gas velocity and temperature in a pulse tube refrigerator, Adv. Cryog. Eng. 37B (1992) 939

3）矢崎太一ら：レーザー流速計を用いたパルス管
内部の流速測定, 第 52 回 1994 年度秋季低温工 学・超電導学会講演概要集 (1994) 219

4) J. M. Lee, et al.: Flow patterns intrinsic to the pulse tube refrigerator, Cryocoolers 7 Part 1 (1993) 125

5) S.W. Zhu and Z.Q. Chen: Isothermal model of pulse tube refrigerator, Cryogenics 34 (1994) 591

6) C. Wang: Numerical analysis of $4 \mathrm{~K}$ pulse tube coolers: Part I. Numerical simulation, Cryogenics 37 (1997) 207

7) S.W. Zhu and Y. Matsubara: Proposal for a tube expander, Cryogenics 36 (1996) 403

8）日本機械学会編：機械工学便覽 (新版), 丸善, 東京 (1987) B 応用編 B 5-209

9）鎌倉友男：超音波における非線形現象，ながれ 16 (1997) 226

10) A. Tominaga: Thermodynamic aspects of thermoacoustic theory, Cryogenics 35 (1995) 427

11）富永 昭：第 3 回波動熱輸送研究会配布資料, テキスト「熱音響工学入門」(仮題) 第四章, 1995 年 8 月 25 日

12）矢崎太一ら：パルス管内部の流体の動的挙動の 直接観察 II - 可視化, 第 53 回 1995 年度春季低 温工学・超電導学会講演概要集 (1995) 188 